\title{
Immune Thrombocytopenia as the Initial Manifestation of Pediatric Systemic Lupus Erythematosus: Case Reports
}

\author{
Harapan Parlindungan Ringoringo*(i) \\ Department of Child Health, Faculty of Medicine, Lambung Mangkurat University, RSD Idaman Banjarbaru, Banjarbaru, Indonesia
}

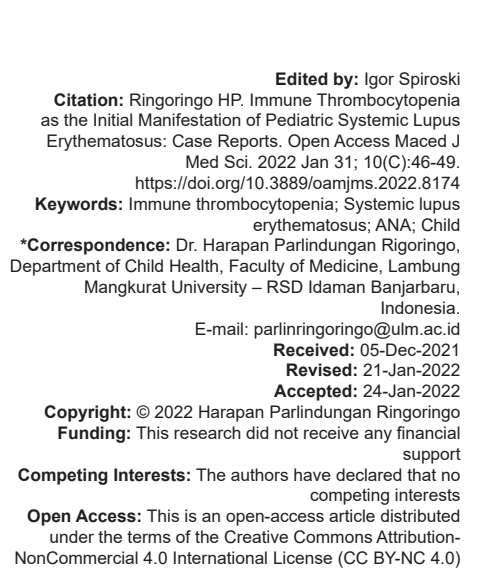

Abstract

BACKGROUND: Immune thrombocytopenia (ITP) can precede the onset of systemic lupus erythematosus (SLE) by months to years.

CASE PRESENTATION: A 12-year-old girl weighing $46 \mathrm{~kg}$ came to the hospital with the complaint of 12 daysmenstrual bleeding. The patient is weak, pale. Eyes, ENT, heart, lungs, abdomen: within normal limits, no petechiae. Laboratorium: Hemoglobin $(\mathrm{Hb}) 4.6 \mathrm{~g} / \mathrm{dL}$, leukocytes 12,930/uL, platelets 11,000/uL, hematocrit 15\%, Diff Count: normal. Red blood cell (RBC) 1.59 million/uL, mean corpuscular volume (MCV) $94.3 \mathrm{fL}$, mean corpuscular hemoglobin $(\mathrm{MCH}) 28.9 \mathrm{pg}, \mathrm{MCH}$ concentration 30.7\%, RDW-CV 14.6\%. Corrected-reticulocytes 5.16\%, Ret-He 22.6, IPF $54.17 \%$. Peripheral blood smears normochromic, normocytic, blast not found, platelets are rare. The diagnosis is menometrorrhagia with anemia due to bleeding caused by ITP. The patient was given PRC and platelet transfusion, methylprednisolone. Three months later, the patient had another prolonged menstruation, hair loss, no petechiae, or purpura. Laboratorium: Hb $8.2 \mathrm{~g} / \mathrm{dL}$, leukocytes 7800/uL, platelets 6000/uL, RBC 1.59 million/uL, MCV 94.3fL, MCH 28.9pg, corrected reticulocytes 5.08\%, Ret-He 24.6, IPF 54.5\%. ANA test positive, Anti dsDNA-NcX 190.2 IU/ml. The diagnosis is SLE. During the last 16 months, the patient took $10 \mathrm{mg}$ prednisone with a platelet count $>150,000 / \mathrm{uL}$.

CONCLUSION: In every case of ITP in a child, consider the possibility of SLE.

\section{Introduction}

Immune thrombocytopenia (ITP) can precede the onset of systemic lupus erythematosus (SLE) by months to years. The incidence of pediatric ITP is 4.3/100,000 people/year [1]. The incidence of SLE in patients with ITP and the potential relationship between them is still unclear. Zhu et al. reported that SLE incidence in ITP patients and SLE incidence in non-ITPS was $4.7 \%$ and $0.19 \%$, respectively. ITP patients had a 26 -fold risk of developing SLE than the control group in the population. Furthermore, men have a lower risk of developing SLE than women [2].

\section{Case Presentation}

A 12-year-old girl weighing $46 \mathrm{~kg}$ came to the hospital with the complaint of 12 days-massive menstrual bleeding. Previously the patient had frequent nosebleeds. On physical examination, the patient is conscious, weak, pale. Eyes, ENT, heart, lungs, abdomen: within normal limits, no petechiae. On laboratory tests: $\mathrm{Hb} 4.6 \mathrm{~g} / \mathrm{dL}$, leukocytes
12,930/uL, platelets $11,000 / \mathrm{uL}$, hematocrit $15 \%$, Diff Count: basophils $0 \%$, eosinophils $0 \%$, stems $1 \%$, segments $71 \%$, lymphocytes $24 \%$, monocytes $4 \%$. Red blood cell (RBC) 1.59 million/uL, mean corpuscular volume (MCV) $94.3 \mathrm{fL}$, mean corpuscular hemoglobin (MCH) 28.9pg, $\mathrm{MCH}$ concentration (MCHC $30.7 \%$, RDW-CV 14.6\%. Corrected reticulocytes $5.16 \%$, Ret-He 22.6, IPF 54.17\%. Peripheral blood smear features normochromic, normocytic, blast not found, platelets are rare. The diagnosis is menometrorrhagia with anemia due to bleeding caused by ITP. The patient was given $5 \times 250 \mathrm{ml} \mathrm{PRC}$ transfusion, 10U platelet transfusion, $50 \mathrm{mg}$ of methylprednisolone intravenous every $12 \mathrm{~h}$ for 3 days, followed by $30 \mathrm{mg}$ intravenous for 4 days. The patient went home in good condition. The patient lost to follow-up.

Three months later, the patient had another prolonged massive menstruation, appeared Malar rash on the cheeks, and hair loss in several places on the head. On the skin, there is no petechiae or purpura. Laboratory examinations: $\mathrm{Hb} 8.2 \mathrm{~g} / \mathrm{dL}$, leukocytes $7800 /$ uL, platelets 6000/uL, hematocrit $25.1 \%$, Diff Count: basophils $0 \%$, eosinophils $5 \%$, stems $1 \%$, segments $60 \%$, lymphocytes $29 \%$, monocytes $5 \%$. RBC 1.59 million/uL, MCV 94.3fL, MCH 28.9pg, MCHC $30.7 \%$, RDW-CV $14.6 \%$. Corrected reticulocytes $5.08 \%$, Ret-He 24.6, IPF 54.5\%. Urinalysis within normal limits. 
The patient was given $4 \times 250 \mathrm{ml} \mathrm{PRC}$ transfusion, $2 \times$ $10 \mathrm{U}$ platelet transfusion, $50 \mathrm{mg}$ of methylprednisolone intravenous every $12 \mathrm{~h}$ for 3 days, followed by $30 \mathrm{mg}$ intravenous for 4 days. Immunology examination: ANA test titer 1:1000 (negative < 1:100), Anti dsDNA-NcX $190.2 \mathrm{IU} / \mathrm{ml}$ (negative <100). The diagnosis is SLE. Furthermore, during the past 16 months, the patient took prednisone $2 \times 1$ tablet with a platelet count $>150,000 /$ uL. When the prednisone dose is lowered, it will cause the cheeks' redness, an uncomfortable stomach, and weakness.

\section{Discussion}

Initially, the patient was diagnosed with newly ITP based on 12 days-massive menstrual bleeding, platelets of $11,000 / \mathrm{uL}$, and platelets on the peripheral blood smear were rarely found. $\mathrm{Hb} 4.6 \mathrm{~g} / \mathrm{dL}$ means that there has been a lot of blood loss, which is undoubtedly life-threatening. Therefore, the therapy is given PRC transfusion and platelet transfusion, followed by $2 \mathrm{mg} / \mathrm{kg}$ body weight of methylprednisolone for 7 days. This therapy suits the theory that if there is life-threatening bleeding and the platelets are $<30,0000 /$ uL, we should give platelet transfusions and methylprednisolon as first-line ITP drugs [3], [4]. Patients are not given IVIG because it is expensive; the patient's family cannot afford it. When the patient went home, he was given prednisone, but unfortunately, the patient lost to follow-up. We do not know whether this patient will develop persistent/chronic ITP, but the likelihood of developing chronic ITP is high. ITP in children $\geq 120$ months, $47 \%$ will be chronic ITP [5]. Jung et al. stated that $85.9 \%$ of pediatric ITP would be in remission, and $14.1 \%$ of cases will become chronic ITP; the prognostic factor for chronic ITP is the older child's age [6]. Makis et al. stated that a person's prognostic factor in developing chronic ITP is age $>10$ years [7].

Three months later, the patient experienced massive menstrual bleeding accompanied by a Malar rash on the cheeks (butterfly appearance) and hair loss in several places on the head. With clinical findings in vaginal bleeding, Malar rash on the cheeks, hair loss, platelets of $6000 / \mathrm{uL}$, the patient is suspected of having SLE. It turned out that the ANA examination was confirmed positive, and anti-dsDNA-NcX was positive. Based on the SLICC criteria to determine SLE'S diagnosis, which requires the fulfillment of $\geq 4$ criteria out of 17 criteria with at least one clinical or laboratory criterion being met and at least one immunological examination criteria met, this patient was diagnosed with SLE. SLE criteria, according to SLICC, can be seen in Table 1 [8].

The mechanism by which ITP becomes SLE is not known. There are two principal causes of ITP:
Table 1: SLICC ${ }^{\dagger}$ Classification Criteria [8]

\begin{tabular}{ll}
\hline Clinical criteria & Immunologic criteria \\
\hline Accute cutaneous lupus & ANA \\
Chronic cutaneous lupus & Anti-DNA \\
Oral or nasal ulcers & Anti-Sm \\
Non-scarring alopecia & Antiphospholipid Ab \\
Arthritis & Low complement (C3, C4, CH50) \\
Serositis & Directs Coombs' test (do not count \\
Renal & in the presence of hemolythic \\
& anemia) \\
Neurologic & \\
Hemolythic anemia & \\
Leukopenia & \\
Thrombocythopenia & \\
$\left(<100,000 /\right.$ mm $\left.^{3}\right)$ & \\
\hline${ }^{\dagger}$ SLICC: System Lupus International Collaborating Clinics. Requirements: $\geq 4$ criteria (at least 1 clinical and \\
1 laboratory criteria) OR biopsy-proven lupus nephritis with positive ANA or Anti-DNA.
\end{tabular}

megakaryocyte maturation disorder, insufficient platelet production, and antibody-mediated platelet destruction exceeding bone marrow compensatory capacity. For ITP of autoimmune etiology, the glycoproteins (GP) expressed on the platelet surface (mainly GPIIb/ IIla and Ib/IX) are recognized by the immune system as foreign antigens, leading to the generation of autoantibodies. The subsequent interaction between the Fc segment of the autoantibody and Fc gamma receptor $(F c \gamma R)$ on the macrophage surface results in platelet destruction through phagocytosis [9]. Analyses have shown an increased frequency of antiplatelet antibodies in SLE patients with thrombocytopenia compared with SLE patients without thrombocytopenia. Antithrombopoietin receptor antibodies have been detected in higher frequency in patients with SLE who have thrombocytopenia than those who do not have a low platelet count [10], [11], [12], [13], [14].

Thrombocytopenia is a poor prognostic factor in SLE [15]. Thrombocytopenia is a frequent clinical manifestation of SLE [16]; 3-16\% of ITP patients become SLE [17]. Zhao et al. reported that ITP initiated $12.8 \%$ of cases of SLE [18]. Hazzan et al. reported that of 222 ITP patients, under a 4.2-year follow-up, 3.6\% developed SLE, all of which were women, mean age 12.7 years, with positive ANA [19]. In contrast Altintas et al., none of the ITP children with positive ANA developed SLE [20].

After the SLE diagnosis was established, the patient was motivated to remain in control of the doctor and regularly take prednisone medication. The patient was given a dose of prednisone full-dose, and because the platelet count was still $>150,000 / u L$, the prednisone drug was tapering off gradually. The lowest attainable and effective prednisone dose that does not cause clinical symptoms anymore is $10 \mathrm{mg}$. Because once the prednisone dose is lowered, the cheeks' redness develops, and the patient feels weak. Up to 16 months of monitoring, the patient can be clinically controlled with a prednisone dose of $10 \mathrm{mg}$ with a thrombocyte count $>150,000 / \mu \mathrm{L}$.

Treatment of SLE with thrombocytopenia is, in principle, the same as the treatment of ITP. Treatment of ITP must, of course, be based on the complex pathogenesis of ITP. The first-line drugs are 
glucocorticoids, IVIG, anti-D immunoglobulin. Suppose first-line treatment fails (clinical manifestations and thrombocytopenia can not be controlled with in 3-6 months of therapy); in that case, it is necessary to think about treatment with secondline drugs, namely rituximab and thrombopoietin receptor agonists (TPO-RA, such as eltrombopag, romiplostim, and avatrombopag). If second-line drugs are also ineffective, third-line drugs can be used, such as fostamatinib, oseltamivir, atorvastatin [21], [22], [23], low doses of decitabin [24], hydroxychloroquine [25], [26], [27], azathioprine [28], mycophenolate mofetil [26], cyclosporine A [29], and tacrolimus [30].

\section{Conclusion}

In every case of ITP in a child, consider the possibility of SLE. We have to check the ANA test as a screening.

\section{References}

1. Yong $\mathrm{M}$, Schoonen WM, Li L, Kanas G, Coalson J, Mowat $\mathrm{F}$, et al. Epidemiology of paediatric immune thrombocytopenia in the general practice research database. $\mathrm{Br} \mathrm{J}$ Haematol. 2010;149(6):855-64. https://doi. org/10.1111/j.1365-2141.2010.08176.x

PMid:20377590

2. Zhu FX, Huang JY, Ye Z, Wen QQ, Wei JC. Risk of systemic lupus erythematosus in patients with idiopathic thrombocytopenic purpura: A population-based cohort study. Ann Rheum Dis. 2020;79(6):793-9. https://doi.org/10.1136/ annrheumdis-2020-217013

PMid:32241798

3. Neunert C, Lim W, Crowther M, Cohen A, Solberg L Jr., Crowther MA, et al. American Society of Hematology. The American society of hematology 2011 evidencebased practice guideline for immune thrombocytopenia. Blood. 2011;117(16):4190-207. https://doi.org/10.1182/ blood-2010-08-302984 PMid:21325604

4. Provan D, Stasi R, Newland AC, Blanchette VS, BoltonMaggs $\mathrm{P}$, Bussel JB, et al. International consensus report on the investigation and management of primary immune thrombocytopenia. Blood. 2010;115(2):168-86. https://doi. org/10.1182/blood-2009-06-225565

PMid:19846889

5. Sandoval C, Visintainer P, Ozkaynak MF, Tugal O, Jayabose S. Clinical features and treatment outcomes of 79 infants with immune thrombocytopenic purpura. Pediatr Blood Cancer. 2004;42(1):109-12. https://doi.org/10.1002/pbc.10458 PMid: 14752803

6. Jung JY, Rum OA, MD, Kim JK, Park M. Clinical course and prognostic factors of childhood immune thrombocytopenia: Single center experience of 10 years. Korean J Pediatr.
2016;59(8):335-40. https://doi.org/10.3345/kjp.2016.59.8.335 PMid:27610182

7. Makis A, Gkoutsias A, Palianopoulos T, Pappa E, Papapetrou E, Tsaousi C, Hatzimichael E, et al. Prognostic factors for immune thrombocytopenia outcome in Greek children: A retrospective single-centered analysis. Adv Hematol. 2017;2017:7878605 https://doi.org/10.1155/2017/7878605

PMid:29362564

8. Petri M, Orbai AM, Alarcón GS, Gordon C Merrill JT, Fortin PR, et al. Derivation and validation of the systemic lupus international collaborating clinics classification criteria for systemic lupus erythematosus. Arthritis Rheum. 2012;64(8):2677-86. https://doi.org/10.1002/art.34473 PMid:22553077

9. Audia S, Mahevas M, Samson M, Godeau B, Bonnotte B. Pathogenesis of immune thrombocytopenia. Autoimmun Rev. 2017;16(6):620-32. https://doi.org/10.1016/j.autrev.2017.04.012 PMid:28428120

10. Macchi L, Rispal P, Clofent-Sanchez G, Pellegrin JL, Nurden P, Leng B, et al. Antiplatelet antibodies in patientswithsystemiclupuserythemato susandtheprimaryantiphospholipid antibody syndrome: Their relationship with the observed thrombocytopenia. $\mathrm{Br} J$ Haematol 1997;98(2):336-41. https://doi. org/10.1046/j.1365-2141.1997.2243038.x PMid:9266930

11. Karpatkin S, Strick N, Karpatkin MB, Siskind GW Cumulative experience in the detection of antiplatelet antibody in 234 patients with idiopathic thrombocytopenic purpura, systemic lupus erythematosus and other clinical disorders. Am J Med. 1972;52(6):776-85. https://doi. org/10.1016/0002-9343(72)90084-8

PMid:5063961

12. Michel $M$, Lee $K$, Piette JC, Fromont $P$, Schaeffer $A$ Bierling $\mathrm{P}$, et al. Platelet autoantibodies and lupus-associated thrombocytopenia. Br J Haematol. 2002;119(2):354-8. https:// doi.org/10.1046/j.1365-2141.2002.03817.x PMid:12406068

13. Ishikawa A, Okada J, Kondo H. Antiplatelet antibodies in sera from patients with systemic lupus erythematosus by immunoblot analysis. Nihon Rinsho Meneki Gakkai Kaishi. 1995;18(1):20-8. https://doi.org/10.2177/jsci.18.20 PMid:7553035

14. Kuwana M, Kaburaki J, Okazaki Y, Miyazaki H, Ikeda Y. Two types of autoantibody-mediated thrombocytopenia in patients with systemic lupus erythematosus. Rheumatology (Oxford). 2006;45(7):851-4. https://doi.org/10.1093/rheumatology/kel010 PMid: 16418192

15. Scofield RH, Bruner GR, Kelly JA, Kilpatrick J, Bacino D, Nath SK, et al. Thrombocytopenia identifies a severe familial phenotype of systemic lupus erythematosus and reveals genetic linkages at 1q22 and 11p13. Blood. 2003;101(3):992-7. https:// doi.org/10.1182/blood-2002-04-1003 PMid:12393658

16. Fayyaz A, Igoe A, Kurien BT, Danda D, James JA, Stafford HA, et al. Haematological manifestations of lupus. Lupus Sci Med. 2015;2(1):e000078. https://doi.org/10.1136/lupus-2014-000078 PMid:25861458

17. Hakim AJ, Machin SJ, Isenberg DA. Autoimmune thrombocytopenia in primary antiphospholipid syndrome and systemic lupus erythematosus: The response to splenectomy. Semin Arthritis Rheum. 1998;28(1):20-5. https://doi.org/10.1016/ s0049-0172(98)80024-3

PMid:9726332

18. Zhao H, Li S, Yang R. Thrombocytopenia in patients with 
systemic lupus erythematosus: Significant in the clinical implication and prognosis. Platelets. 2010;21(5):380-5. https:// doi.org/10.3109/09537101003735564

PMid:20433308

19. Hazzan R, Mukamel M, Yacobovich J, Yaniv I, Tamary H. Risk factors for future development of systemic lupus erythematosus in children with idiopathic thrombocytopenic purpura. Pediatr Blood Cancer. 2006;47(5):657-9. https://doi.org/10.1002/ pbc. 20970

PMid:16933242

20. Altintas A Ozel A, Okur N, Okur N, Cil T, Pasa S, et al. Prevalence and clinical significance of elevated antinuclear antibody test in children and adult patients with idiopathic thrombocytopenic purpura. J Thromb Thrombolysis. 2007;24(2):163-8. https://doi. org/10.1007/s11239-007-0031-y

PMid: 17436144

21. Dou X, Yang R. Current and emerging treatments for immune thrombocytopenia, Expert Rev Hematol. 2019;12(9):723-32. https://doi.org/10.1080/17474086.2019.1636644

PMid:31237783

22. Despotovic JM.Emerging therapies in immune thrombocytopenia. The Hematologist. 2018;15(4). https://doi. org/10.1182/hem.V15.4.8728

23. Zufferey A, Kapur R, Semple JW. Pathogenesis and therapeutic mechanisms in immune thrombocytopenia (ITP). J Clin Med. 2017;6(2):16. https://doi.org/10.3390/jcm6020016 PMid:28208757

24. Liua S, Shan N. DNA methylation plays an important role in immune thrombocytopenia. Int Immunopharmacol. 2020;83:106390. https://doi.org/10.1016/j.intimp.2020.106390

\section{PMid:32193101}

25. Arnal C, Piette JC, Leone J, Taillan B, Hachulla E, RoudotThoraval F, et al. Treatment of severe immune thrombocytopenia associated with systemic lupus erythematosus: 59 cases. J Rheumatol. 2002;29(1):75-83.

PMid: 11824975

26. KadoR,McCuneWJ.Treatmentofprimaryand secondaryimmune thrombocytopenia. Curr Opin Rheumatol. 2019;31(3):213-22. https://doi.org/10.1097/BOR.0000000000000599 PMid:30920453

27. Mohammadpour F, Kargar M, Hadjibabaie M. The role of hydroxychloroquine as a steroid-sparing agent in the treatment of immune thrombocytopenia: A review of the literature. J Res Pharm Pract. 2018;7(1):4-12. https://doi.org/10.4103/jrpp.JRPP_17_60 PMid:29755993

28. Jung JH, Soh MS, Ahn YH, Um YJ, Jung JY, Suh $\mathrm{CH}$, et al. Thrombocytopenia in systemic lupus erythematosus: Clinical manifestations, treatment, and prognosis in 230 patients. Medicine (Baltimore). 2016;95(6):e2818.

29. Quartuccio L, Sacco S, Franzolini N, Perin A, Ferraccioli G, de Vita S. Efficacy of cyclosporin-A in the long-term management of thrombocytopenia associated with systemic lupus erythematosus. Lupus. 2006;15(2):76-9. https://doi. org/10.1191/0961203306lu2266oa

PMid: 16539277

30. Li Y, Feng X. Efficacy and safety of tacrolimus in systemic lupus erythematosus patients with refractory thrombocytopenia: A retrospective study. Lupus. 2018;27(1):60-5. https://doi. org/10.1177/0961203317711011

PMid:28566017 